\title{
焼結原料造粒における水分分布の 擬似粒子形成への影響
}

\author{
松村 勝* ・川口 尊三*
}

Effect of Moisture Distribution of Sinter Mixture on Granulating Particles

Masaru Matsumura and Takazo KaWAGUCHI

Synopsis : For increase of sinter productivity, it is important to design sinter mixture granulation methods of moisture content, moisture distribution, and mixing method.

In order to design them, especially moisture distribution and its transformation with mixing, laboratory granulation tests were carried out. These tests were moisture absorption rate for a coarse iron ore $(4-6 \mathrm{~mm})$, adhesion of low moisture content fine iron ore $(-0.25 \mathrm{~mm})$ and one pseudo-particle coated with high moisture content fine ore, and granulation of coarse and fine ores with varying initial and adding moisture distribution and mixing method with a drum mixer and a high speed agitating mixer.

The main results obtained are as follows:

(1) It took over $5 \mathrm{~h}$ to absorb moisture to coarse ore surrounded by raw sinter materials with 6 mass $\%$ moisture.

( 2 ) When adhering low moisture content fine to pseudo-particles coated with high moisture content adherent fine ores, final moisture content of total adherent fine converged to a constant value.

( 3 ) With mixing by a drum mixer, high moisture content fine adhered first to coarse. Next, low moisture content fine adhered to the coarse coated with high moisture content adherent fine. Then, pseudo-particle size distribution depended on moisture distribution of fine as well as ratio of coarse and fine. Pseudo-particle size distribution was sharper, when moisture distribution of fine was sharper and ratio of fine was lower.

On the other hand, with mixing by a high speed agitating mixer, moisture distribution of fine went homogeneous before adhering. This result suggests that adhering and collapse occurred at a same time. With mixing by a drum mixer after mixing by a high speed agitating mixer, pseudo-particle size distribution was sharpest.

Key words: sinter; granulation; pseudo-particle; moisture transfer; rolling; agitating; adherence.

\section{1. 緒言}

焼結原料中の水分は焼結鉱製造における生産性に多大な る影響を及ぼす。これは水分が原料の造粒性や通気性に深 く関係していること，さらには焼成時の燃焼効率や燃焼前 線降下速度に深く関係していることによる ${ }^{1-5) 。 こ こ て ゙ ， ~}$ 焼結における造粒では，10 $\mathrm{mm}$ 以下の幅広い粒度分布を持 つ鉱石に水を添加し転動晩找作用を加えることで，粒径の 小さい粉を水の毛管付着力で凝集させ，擬似粒子化する。

さて，この原料の擬似粒子化は，粗粒鉱石を核として粉 鉱石を雪だるま式に付着成長する形でなされていることを 特徵としている。よって原料鉱石の鉱石特性や付着成長を 助長する造粒操作条件に大きな影響を受ける。鉱石特性と しては，粒度分布，粘着性，表面性状，粒子形状，鉱石内 への吸水量などが挙げられる ${ }^{2,3)}$ 。また造粒操作条件とし ては混合・造粒時間，回転速度，粒子転動距離などが挙げ られる4)。さらに水分量を変更すると造粒された擬似粒度
分布も大きく異なることが，実験的に裏づけされている また, 最近では加納らの離散要素法による粒子運動の研究 が試みられている7。

一方，実用化技術として，単純に鉱石を一括混合する方 法から，鉱石特性を考慮し鉱石分布を高度に設計して焼結 鉱の品質と焼結生産性を図る複合造粒法が採用されてい

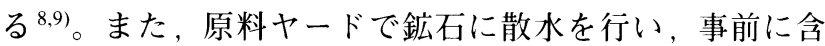

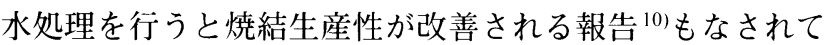
いる。

ここで，原料の最終的な擬似粒子化状態が，造粒時の平 均的な水分ばかりでなくヤードでの散水や降雨によって生 産性が変化することは，原料の平均水分ばかりでなく水の 分布やその時間的な変化にも左右されることを示してい る。そこで，本研究では，モデル原料として単一銘柄の粗 粒（粒径 4-6 mm） および粉（粒径 $-0.25 \mathrm{~mm}$ ）を、混合機 として高速擋挥ミキサーとドラムミキサーを用いて，(1)非 混合状態における時間的な粗粒の水分変化(2)粉の他粒子へ

平成 12 年 8 月 31 日受付 平成 13 年1月9日受理 (Received on Aug. 31, 2000; Accepted on Jan. 9, 2001)

* 住友金属工業 (株) 総合技術研究所 (Corporate Research \& Development Laboratories, Sumitomo Metal Industries, Ltd., 16-1 Oaza-Sunayama Hasakimachi Kashimagun Ibaraki-ken 314-0255) 
の付着挙動調査(3)水の分布条件と混合機機種の擬似粒度分 布への影響を調査することによって，水の原料中での賦存 状態や移動現象に着目して, 水の移動および擬似粒子の形 成挙動について考察した。

\section{2. 実験方法}

\section{$2 \cdot 1$ 粗粒鉱石の吸水速度試験}

原料を混合しない状態で，鉱石粒子の初期水分に差が あった場合の水分移動速度を確認することを目的として， 吸水速度試験を実施した。まず, $105^{\circ} \mathrm{C} 2$ 時間乾燥した豪 州産赤鉄鉱（H鉱石）の，単一粒子（サイズ：10×15× $8 \mathrm{~mm} ） を ， 200 \mathrm{~g}$ の水中，または水分 $6 \%$ の造粒後の実機 配合原料 $100 \mathrm{~g}$ に浸漬させた。所定時間経過後, この単一 粒子を取出し，表面水を拭き取り，この粒子の水分を測定 した。水分値は $105^{\circ} \mathrm{C} 2$ 時間乾燥処理の前後の重量変化か ら算出した。同一粒子を用いて，浸漬時間を変化させつつ この一連の作業（粗粒乾燥 $\rightarrow$ 粗粒重量計測 $\rightarrow$ 浸漬 $\rightarrow$ 粗粒 重量計測 $\rightarrow$ 粗粒乾燥) を繰り返して, 単一粒子の浸漬時 間と水分值との関係を求めた。

\section{$2 \cdot 2$ 単一凝似粒子における粉付着成長試験}

造粒機内では, 散水の不均一性により, 加水直後に比較 的水分の高い初期擬似粒子が形成され，その後の転動作用 により，その高水分擬似粒子のまわりに水分の低い粉が付 着成長すると考えられる。ここでは, 高水分初期擬似粒子 として核のあるものと粉のみのものの 2 通りについて, 高 水分初期擬似粒子への低水分粉の付着限界を調べた。

核のある高水分初期擬似粒子は，ビーカー内で $4-6 \mathrm{~mm}$ の $\mathrm{H}$ 鉱石を核とし，それに $-0.25 \mathrm{~mm}$ の $\mathrm{H}$ 鉱石と水を徐々 に添加し摚找棒でよく混合して調整した。水分は 13 mass\%に調湿し，混合後サンプルの一部を採取し乾燥によ る重量変化で確認した。なお，核鉱石は付着粉からの水分 移動を防止する目的で，吸水飽和状態とし， $24 \mathrm{~h}$ 水浸漬し て遠心分離器にかけて表面付着水を除去したものを用い た。遠心分離処理後の核鉱石の水分は $3.6 \mathrm{mass} \%$ であった。

粉のみからなる高水分初期擬似粒子は， $500 \mathrm{cc}$ 仕様の ビーカー内に試料を加え，振動を加えることにより球形に 整形して調整した。なお，初期擬似粒子の大きさを变更す る目的で高水分粉量は $1 \sim 4 \mathrm{~g}$ まで変更した。

前記初期擬似粒子に付着させる低水分粉および乾燥粉に は $-0.25 \mathrm{~mm}$ の $\mathrm{H}$ 鉱石を用い，水分は各々 $4.3 \mathrm{mass} \%$ おうび 0.0 mass $\%$ に調湿した。 $4.3 \mathrm{mass} \%$ の調湿は高水分粉と同一 方法, 0.0 mass\% の調湿は乾燥機で $105^{\circ} \mathrm{C} 24 \mathrm{~h}$ 乾燥した。

前記初期擬似粒子に前記低水分粉や乾燥粉を付着させ て, その付着限界を求める実験では, 初期擬似粒子をビ一 カーに入れ, 次に低水分粉を $0.5 \mathrm{~g}$ 添加し, ビーカーを手 で振動混合して付着させた。すべての低水分粉の付着完了 後, さらに低水分粉 $0.5 \mathrm{~g}$ 添加し, 同一方法で付着させた。
この一連の操作を付着が飽和するまで実施した。付着飽和 後, 擬似粒子を乾燥処理し, 付着粉全体の水分および質量 を計測した。

\section{$2 \cdot 3$ モデル原料による造粒実験}

$2 \cdot 3 \cdot 1$ 目的

造粒操作において，造粒後の水分だけではなく，原料の 初期水分值 ${ }^{10)}$ p混合方法が異なると擬似粒度分布が变化す ることが知られている。この挙動解明を目的として，擬似 粒子の核として機能する粗粒と付着粉として機能する粉に 単純化したモデル原料を，高速擋找ミキサーおよびドラム ミキサーを用いて混合処理を行った。

$2 \cdot 3 \cdot 2$ 原料および調湿条件

前記モデル原料のうち, 粗粒は粒径 4-6 mm の H 鉱石, 粉は- $025 \mathrm{~mm}$ の H鉱石を用いた。単一擬似粒子に打ける粉 付着成長試験と同様に，付着粉から粗粒への水分移動を防 止する目的で粗粒鉱石は吸水飽和状態（水分值 3.6 mass \%) とした。また，粉では調湿量の異なる $(0.0 \mathrm{mass} \%, 7.0$ mass\%) 2 種類を準備した。

\section{$2 \cdot 3 \cdot 3$ 水分添加および混合処理}

各ミキサー（ドラムミキサーもしくは高速摚找ミキサー） 内に, 乾燥質量換算で粉と粗粒の計 $12 \mathrm{~kg}$ 原料を, 粗粒を 下に粉を上に敷設し添加水分を所定量散布した後， 1 分間 混合した [混合 1 分段階]。この各ミキサーによる 1 分間混 合後，ドラムミキサーでさらに 4 分間混合した [混合 5 分 段階]。実験に使用したドラムミキサーおよび高速擋抖ミ キサーの仕様を Table 1 に示す。

\section{$2 \cdot 3 \cdot 4$ 調査項目および実験方法}

混合 1 分段階および混合 5 分段階において，擬似粒度分 布および擬似粒度別の付着粉水分を調査した。擬似粒度に ついては，原料を $500 \pm 100 \mathrm{~g}$ まで縮分した後に，ふるい分 けし， $105^{\circ} \mathrm{C} 2$ 時間乾燥後各粒度の質量を測定した。擬似 粒度別の付着粉水分については，6-8, 8-10,+10 mmの擬 似粒子それぞれ20個ずつまとめて，擬似粒子全体の湿潤 質量を計測し，次いで乾燥 $\left(105^{\circ} \mathrm{C} 2\right.$ 時間）後の質量を計 測し，さらにこの乾燥後擬似粒子を $0.5 \mathrm{~mm}$ 節上で水洗し て周りの付着粉を除去して乾燥 $\left(105^{\circ} \mathrm{C} 2\right.$ 時間）後の粗粒 鉱石の質量を計測し，これら 3 つ計測値と乾燥前の粗粒 水分值 $3.6 \mathrm{mass} \%$ から算出した。ここで，粗粒の粒径は 4-6 mmなので, 粒径-2 mmは未付着粉量とみなした。ま

Table 1. Specifications of drum mixer and high speed agitating mixer.

\begin{tabular}{|l|c|c|}
\hline & $\begin{array}{l}\text { drum } \\
\text { mixer }\end{array}$ & $\begin{array}{l}\text { high speed } \\
\text { agitating mixer }\end{array}$ \\
\hline $\begin{array}{l}\text { Diameter(mm) } \\
\text { pan } \\
\text { agitater }\end{array}$ & 600 & 325 \\
\hline Pan height (mm) & 200 & 115 \\
\hline $\begin{array}{l}\text { Revolution(rpm) } \\
\text { pan } \\
\text { agitater }\end{array}$ & 24 & 39 \\
\hline Number of agitater & - & 1200 \\
\hline $\begin{array}{l}\text { Capacity of raw } \\
\text { material (kg) }\end{array}$ & 20 & 15 \\
\hline
\end{tabular}


た，付着粉率は粉全体量を分母として算出した。

\section{3. 実験結果}

\section{3 . 1 粗粒鉱石の吸水速度}

粗粒鉱石水分值と浸漬時間との関係を Fig. 1に示す。水 浸漬，鉱石浸漬によらず粗粒鉱石水分值は最終的に 2.7 mass\%に達した。この 24 時間経過時の到達水分值を飽 和水分値と考えれば，水浸漬の場合には，粗粒鉱石水分値 は実験開始から 30 分で飽和水分值の $80 \%$ に達した。一方， $6 \mathrm{mass} \%$ 水分の造粒後原料への浸漬の場合には，飽和水分 值の $80 \%$ に達するのに 5 時間を要した。

\section{$3 \cdot 2$ 単一擬似粒子における粉付着成長}

Fig. 2 に, 初期擬似粒子の付着粉量と，付着粉増加量お よび混合後の付着粉水分との関係を示す。Fig. 2(a)より初 期水分值が同じであれば，造粒後の付着粉増加量と初期擬 似粒子の付着粉量は正比例する。さらに，添加粉水分值が $4.3 \mathrm{mass} \%$ （）の場合での初期擬似粒子の付着粉量の変 化に対する造粒後の付着粉増加量の変化度は，0.0 mass\% （○）の場合での上昇度と比較して大きい。この上昇度は 粗粒内包の有 (O) 無 (O) によらない。Fig. 2(b)より初期 擬似粒子付着粉量, 粗粒内包の有無, 添加粉水分值によら ず，造粒後擬似粒子の付着粉水分值は $9 \sim 10 \mathrm{mass} \%$ で一定 となった。以上のことから，擬似粒子成長の飽和は，造粒 後の擬似粒子径に関係なく，付着粉の水分值に支配される といえる。そして，最終的に付着粉全体の水分値がある一 定の值（H鉱石の場合，9 10 mass\%）となる条件で限界 に達するものと考えられる。

\section{$3 \cdot 3$ モデル原料による水分添加造粒実験}

Fig. 3には諸条件を変更した場合における粉全体の水分 值と付着粉率との関係を示す。なお，粉全体の水分值は， 粉初期水分の量に添加水分の量を加えて粉の質量で割った 值とした。粗粒鉱石には事前に吸水飽和が施されているの で，造粒時に粗粒鉱石への吸水がないと考えられ，粉初期 水分と添加水分が粉の付着に関与するとみなした。Fig. 3 より，各ヶース共に粉全体の水分值が上昇すると付着粉率

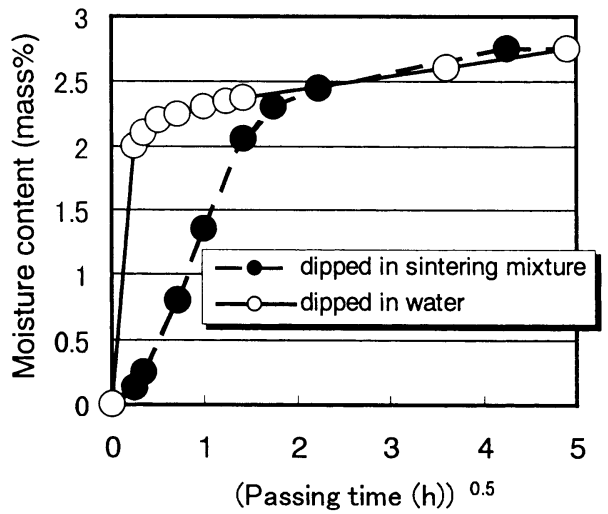

Fig. 1. Absorbing rate of moisture into coarse ore.
が上昇し $100 \%$ に収れんする。また，粉全体の水分が 7 9\%の領域では，粉初期水分值 7\% (○，、）のケースは $0.0 \%(\bigcirc)$ のケースよりも付着粉率が低く，高速摚拌ミキ サーで混合したケース（口）はドラムミキサーで混合した ケース（○）よりも付着粉率が低い。

次に付着粉率が $100 \mathrm{mass} \%$ になった粉平均水分值 11 mass\%付近での擬似粒度分布および粒度別水分につい

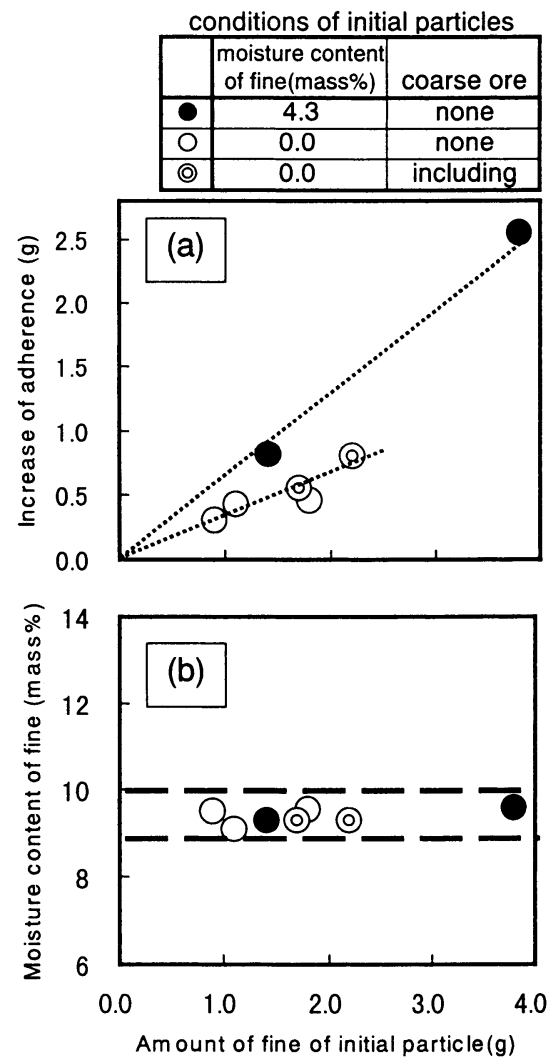

Fig. 2. Relationship between amount of initial adherent fine, and increase and moisture content of adherent fine after granulation

\begin{tabular}{|c|c|c|c|}
\hline & $\begin{array}{l}\text { mixer for first } \\
1 \text { min mixing }\end{array}$ & $\begin{array}{l}\text { initial moisture } \\
\text { content of fine } \\
\text { (mass\%) }\end{array}$ & $\begin{array}{l}\text { coarse:fine } \\
\text { ratio }\end{array}$ \\
\hline$\square$ & $\begin{array}{c}\text { high speed } \\
\text { agitating mixer }\end{array}$ & 0.0 & $3: 7$ \\
\hline 0 & drum mixer & 0.0 & $3: 7$ \\
\hline & drum mixer & 7.0 & $3: 7$ \\
\hline$\Delta$ & drum mixer & 7.0 & $6: 4$ \\
\hline
\end{tabular}

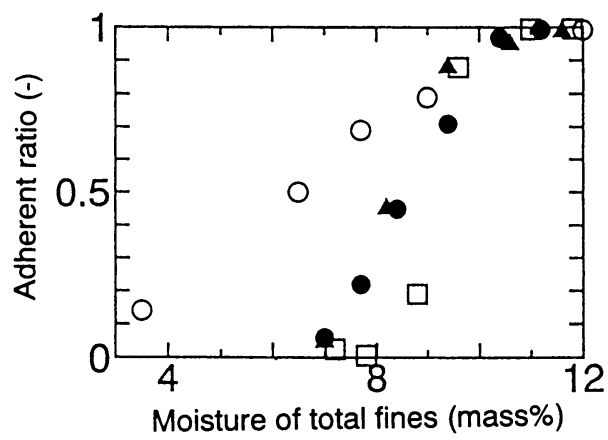

Fig. 3. Effect of calculated moisture content in total fine on adherent ratio after 5 min mixing. 


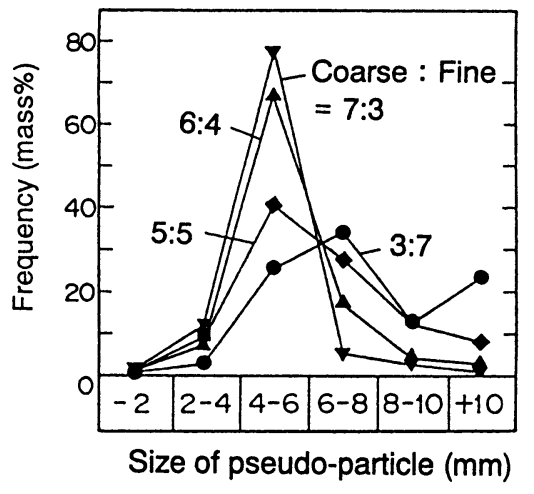

Fig. 4. Effect of coarse and fine ratio on pseudo-particles size distribution after 5 min mixing.

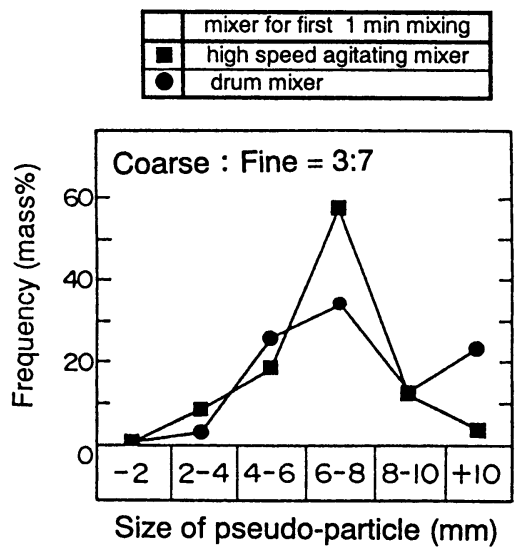

Fig. 5. Effect of first 1 min mixing method on pseudo-particles size distribution after 5 min mixing.

て述べる。Fig. 4にはドラムミキサーのみで混合した場合 での混合 5 分段階における粉／粗粒の配合比率の擬似粒度 分布への影響を示す。粉／粗粒比率の上昇とともに擬似粒 度分布が広がった。Fig. 5 には粉比率が $70 \mathrm{mass} \%$ と高い条 件(Coarse : Fine=3:7)での混合 5 分段階における 1 分間混合 ミキサーの相違の影響を示す。高速摚找ミキサーによる混 合はドラムミキサーによる混合と比較して擬似粒度分布が 狭まった。Fig. 6 に混合 1 分段階における擬似粒度分布を， Fig. 7 に混合 1 分段階および混合 5 分段階における $+6 \mathrm{~mm}$ の擬似粒子における付着粉水分值と未付着粉水分值との差 分を擬似粒度別に示す。Fig. 6の混合1分段階においては， 高速摚拌ミキサーによる混合では未付着粉比率が高く, 粉 の粗粒への付着が進行していないことがわかる。一方，ド ラムミキサーによる混合では未付着粉の比率が低く，また 擬似粒度も幅広く分布して打り，この段階で既に粉の粗粒 へ不均等な付着がかなり進行していることが理解される。

また，Fig. 7では，高速摚拌ミキサーによる1分混合段 階で既に未付着粉と付着粉との水分差が小さく，粉の水分 均一化がよく進行していることが理解される。一方，ドラ ムミキサーの場合には，未付着粉と付着粉との水分差が大 きく，粉水分值の均一化があまり進行していないことが理

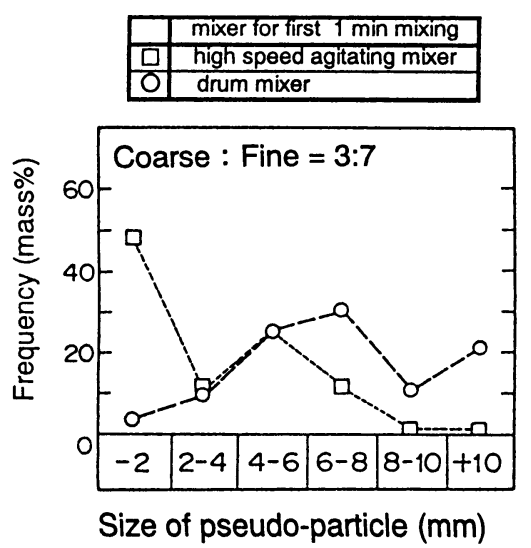

Fig. 6. Effect of first 1 min mixing method on pseudo-particles size distribution after 1 min mixing.

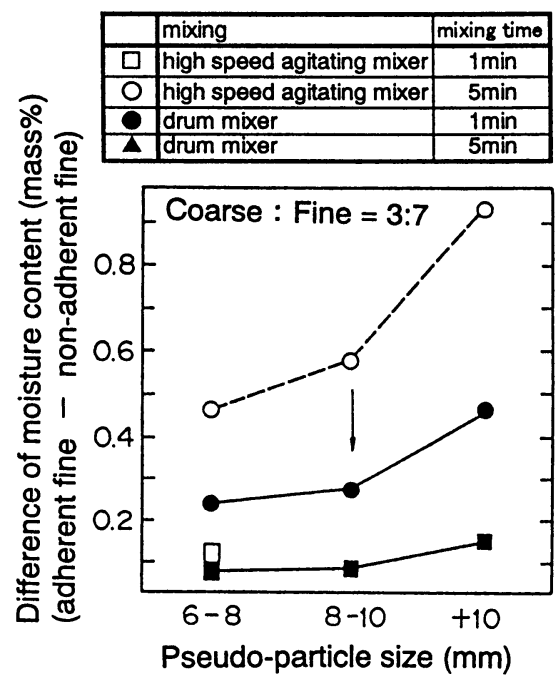

Fig. 7. Moisture content difference between non-adherent fine $(-2 \mathrm{~mm})$ and adherent fine for each pseudoparticles size after $1 \mathrm{~min}$ and more $4 \mathrm{~min}$ granulating.

解される。しかし，ドラムミキサーによる4分間の混合が 加わると水分差がなくなり, 粉水分の均一化がほとんど完 了し造粒が安定に達していることが理解される。

\section{4. 考察}

\section{$4 \cdot 1$ 非混合時水分移動}

まず，原料が混合を受けない状態，すなわち，造粒後に 擬似粒子がベルトコンベアーで焼結機への搬送における水 分移動について考察する。Fig. 1より乾燥粗粒鉱石の造粒 後原料中への浸漬によって, 造粒後原料の水分が乾燥粗粒 鉱石へ吸収された。これは，水分の分布として，擬似粒子 内空隙や擬似粒子表面での存在よりも，飽和するまで鉱石 内気孔への吸水が優先されることを意味する。これは，粒 子間より鉱石内の毛細気孔径が小さいので，水分未飽和の 鉱石の吸水力が擬似粒子を構成する鉱石の界面張力より大 きいためだと考えられる。 

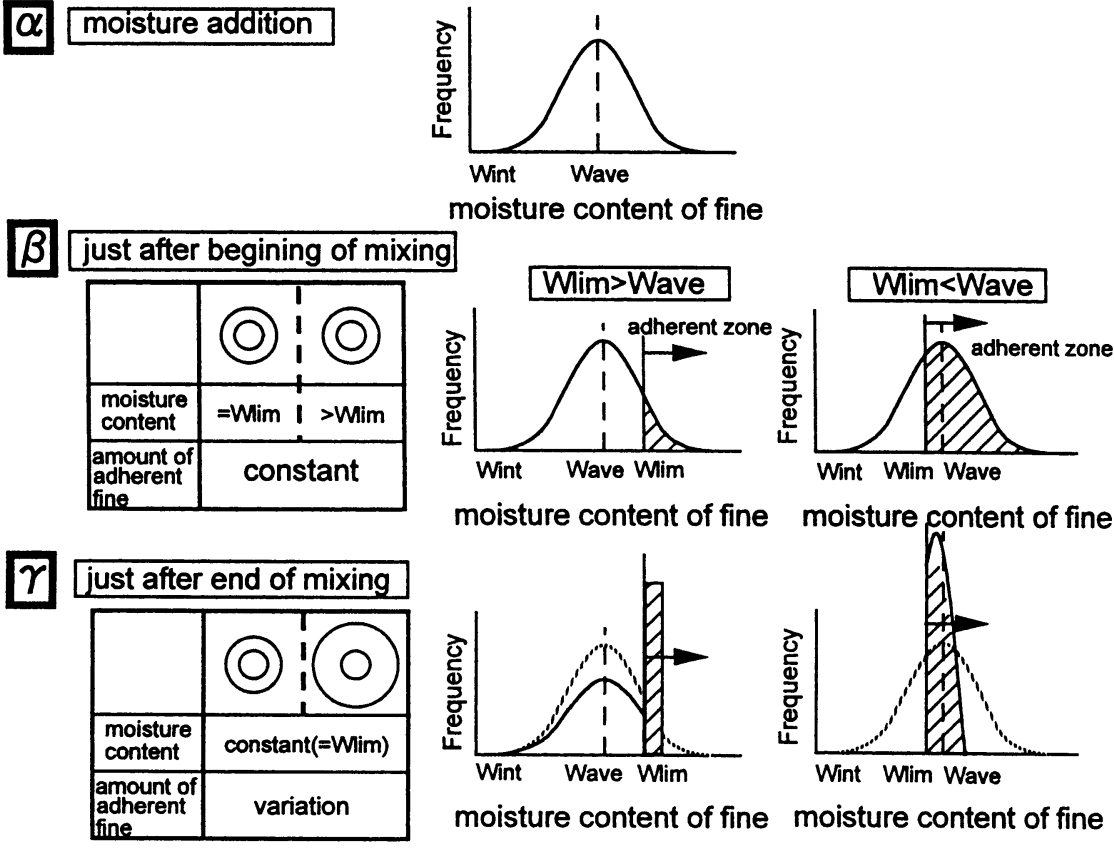

Fig. 8. Concept of change in pseudo-particles structure and moisture distribution of fine by mixing with drum mixer.

鉱石への吸水速度に関しては，水中浸積と比較して，造 粒後原料中への浸漬は低下し，飽和水分の $80 \mathrm{mass} \%$ に達 するのに5時間要した。一方，実プロセスのミキサーでの 混合時間は長くとも 10 分程度である。よって，鉱石内気 孔への吸水が不十分な状態で混合すると，造粒直後に鉱石 内への吸水が未飽和のため，その後鉱石内への吸水によっ て擬似粒子が崩壊することが示唆される。

なお，この水中浸積に対する造粒後原料中への浸漬での 鉱石への吸水速度の低下は，吸水される水に対して，水中 浸積では他鉱石からの界面張力が作用しないのに対し，造 粒後原料中への浸漬では他鉱石からの界面張力が作用する ことによると考えられる。

\section{$4 \cdot 2$ 混合による水分移動と擬似粒子形成}

$4 \cdot 2 \cdot 1$ ドラムミキサーによる混合

次に，原料が混合を受ける状態，すなわち，造粒機内に おける原料粒子間の水分移動と擬似粒子形成挙動について Fig. 8に考察する。なお，考察に際し以下の仮定をおいた。 (1)粗粒および粉は，それぞれ単一粒径に限定。

(2)擬似粒子は，1個の粗粒鉱石の周囲に粉が付着した形態 とする。

(3)水添加時には原料水分分布が存在する。[水添加の不均 一性]。

(4)粉鉱石は付着限界水分 $\left(W_{\lim }\right)$ 以上の水分を含有すると最 初に接触した粒子と付着する。

(5)一度付着した粉は剥離しない。

ここで，付着限界水分 $\left(W_{\mathrm{lim}}\right)$ は， $\mathrm{H}$ 鉱石についてはFig. $2 よ$ り $9.5 \mathrm{mass} \%$ であった。粉が最密充填構造の付着粉層を形 成した場合に空隙率は $26 \mathrm{vol} \%$ と計算される。この空隙率 と鉱石吸水性指数 ${ }^{3)}\left(5.8\right.$ mass\%)，鉱石見掛密度 $\left(4.0 \mathrm{~g} / \mathrm{cm}^{3}\right)$ 上
り，付着限界状態は付着粉層空隙の $40 \%$ を水で埋めた状 態であると計算された。

さてまず水添加によって，粉は水分添加前の粉水分 $\left(W_{\text {int }}\right)$ を最小值とする水分分布が生じると考えられる（Fig. 8 中 $(\alpha))$ 。

次に混合を開始すると，直ちに $W_{\lim }$ 以上の高水分粉が粗 粒に付着して擬似粒子の外㐖を形成する。粗粒と $W_{\lim }$ 以上 の高水分粉の接触機会は粗粒各粒子均等であり粗粒の粒径 は同一なので，この付着粉量は各粒子に均等であると考え られる。ここで付着粉の水分は付着限界水分 $\left(W_{\lim }\right)$ 以上で あり，また混合直後であるので，付着粉と未付着粉とをあ わせた粉全体の水分分布は水添加直後の混合前と同一であ り，粗粒に付着する粉の水分は粒子間で分布を持っている と考えた。換言すれば，混合直後のこの付着は極めて短時 間で行われると考えた。これは Fig. 6 およびFig. 7 におけ るドラムミキサーの転動混合 1 分の段階で未付着粉と付着 粉との水分差が大きく，かつ，かなりの粉が付着している 結果から推察される (Fig. 8中 $(\beta))$ 。

次に混合時間の経過によって，未付着粉である水分 $W_{\lim }$ 以下の低水分粉が，擬似粒子表面に存在する高水分粉に付 着し，粉水分の均一化が進行する。この段階では，付着粉 の量は増加し水分值は低下する。付着する粉の平均水分は $W_{\lim }$ 以下の粉の平均水分で擬似粒子間で差異はない。この 未付着粉の付着は擬似粒子付着粉の水分が $W_{\lim }$ へ低下する まで進行する。よって，混合直後に擬似粒子の外殸を形成 した粉の水分が高いと，付着粉量が多くなる。この付着粉 量の差異が擬似粒度分布を発生させる。なお，粉全体の水 分 $\left(W_{\mathrm{ave}}\right)$ が $W_{\lim }$ 以上の場合には，粉の水分が $W_{\lim } に$ に低下す る前に粉がなくなる。しかし，同じ機構で粉水分の均一化 


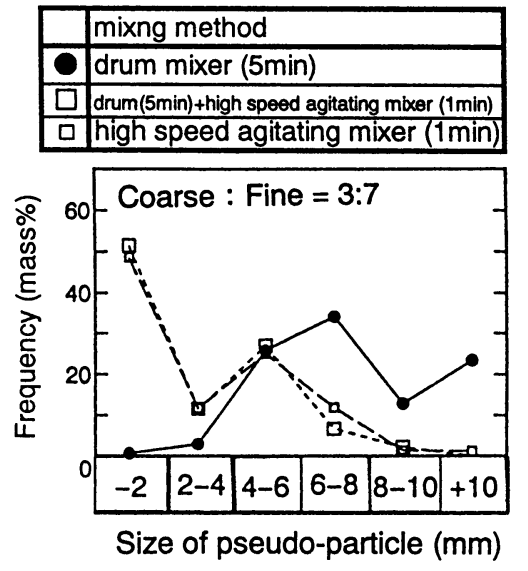

Fig. 9. Change of pseudo-particles size distribution by mixing pseudo-particles with high speed agitating mixer.

と擬似粒度分布は生じる (Fig. 8 中 $(\gamma))$ 。

$4 \cdot 2 \cdot 2$ 高速筧拌ミキサーによる強擋找処理

高速擋拌ミキサーによる混合では Fig. 6 およびFig. 7 に みられるように粉の付着を抑制して粉の水分を均一化して いる。1 分間という短時間での粉水分の均一化には, 高水 分粉と低水分粉との接触が必要であるが，付着粉率が低い 結果から接触によって付着結合を起こしても，擬似粒子は アジテータによる強晩拌作用によって崩壊すると考えられ る。

そこで，この考えを確認するために，モデル原料による 水分添加造粒実験において 5 分間ドラムミキサーで処理し た付着率 $100 \mathrm{mass} \%$ の原料（粗粒：粉 $=3: 7$, 粉初期水分 7.0 mass $\%$ ） を, 高速摚拌ミキサーで混合し，擬似粒度分 布を調査した。結果をFig. 9に示す。高速揊找ミキサーの 混合によって未付着粉が増加し, ドラムミキサーの処理を 行わずに高速挡找ミキサーで混合したケースとほぼ一致し た。すなわち，転動混合で形成した擬似粒子は強筧拌混合 で崩壊する。

また，高速擋拌ミキサーによる混合に続いてドラムミキ サーで混合した場合は，Fig. 5 に示すように擬似粒度分布 幅が狭くなった。これは，粉の付着結合前の段階で粉水分 が均一な状態になる。また粗粒各粒子への粉の接触機会は 等しい。よって, 粉平均水分値が $W_{\lim }$ 以上であれば，粗粒 に付着する粉量が等しくなり擬似粒度は均一化するが, 粉 平均水分值が $W_{\lim }$ よりも低い場合には, 粉は付着力を有せ ず付着は起こらない。

ここまで非混合時および混合時における，水の移動およ び粒子の付着／崩壊について考察した。従来, 吸収性指 数3)等により, 水の原料粒子での分布と粒子の付着結合へ の関与有無とを関連づける概念は導入されていた。また， 高速摚拌ミキサーによる混合処理では，擬似粒度分布が シャープ化しその要因は擬似粒子の崩壊にあること ${ }^{11} は$ 指 摘されていた。今回のモデル試験による検討では，非混合
の系では粒子の吸水力で水の分布が変化する概念や, 混合 の系では粒子の付着結合によって水の分布が時系列に変化 する概念を導入した。高速揊找ミキサーによる混合処理で は一度合体した擬似粒子の崩壊とともに水分が均一化する 概念を導入した。これらの概念から，事前散水による擬似 粒子の崩壊抑制およびドラムミキサーの混合前に高速筧拌 ミキサーによる混合処理による擬似粒度分布のシャープ化 を説明できるに至った。

\section{$4 \cdot 3$ モデル計算による検証}

ここまで記載した概念に基づいて，擬似粒度分布を解析 するモデルを構築し実験結果との整合を検討した。

まず，擬似粒子径は( 1 )式で計算される

$D / D_{c}=\left(\left(M_{c}+M_{f} \cdot R /(1-\varepsilon)\right) / M_{c}\right)^{1 / 3}$

$D_{c}$ : 粗粒粒径 $(\mathrm{m}), D$ : 擬似粒子径 $(\mathrm{m}), M_{c}$ : 粗粒の質量 $(\mathrm{kg})$, $M_{f}$ : 粉の質量 $(\mathrm{kg}), R$ : 粉付着率(一), $\varepsilon$ : 付着粉層内の空隙率 $(-), W_{\mathrm{lim}}$ : 付着限界水分 (mass\%), $W_{\mathrm{int}}$ : 初期水分 $(\mathrm{mass} \%)$

ここで，Rは(2)式で記載される。

$$
R=\left(\int_{W_{\text {lim }}}^{\infty} F d w / \int_{W_{\mathrm{lm}}}^{\infty} F d w\right)
$$

\section{$F:$ 水添加後の水分を变数とする粉の質量分布関数}

また, 混合により粉の水分が変化するとともに, 関数 $F$ も変化する。混合前における粉の質量分布関数を $F_{1}$, 混合 後における粉の質量分布関数を $F_{2}$ とする。

Fig. 8 で記載の混合直後の付着粉量は粗粒各粒子に等し いとすれば上記( 1 )式および ( 2 )式により, 混合直後の擬 似粒子径 $D_{1}(\mathrm{~m})$ と粉付着率 $R_{1}($ 一)は(3)式および $(4)$ 式で 記載される。

$$
\begin{aligned}
& D_{\mathrm{l}} / D_{c}=\left(\left(M_{c}+M_{f} \cdot R_{\mathrm{I}} /(1-\varepsilon)\right) / M_{c}\right)^{1 / 3} . . . \\
& R_{1}=\int_{W_{\text {tim }}}^{\infty} F_{1} d w / \int_{W_{\text {tit }}}^{\infty} F_{1} d w \ldots \ldots \ldots \ldots \ldots . . .
\end{aligned}
$$

一方, 混合終了時の擬似粒子径 $D_{2}(\mathrm{~m})$ と粉付着率 $R_{2}($ 一) は( 5 )式および( 6 )式で記載される。なお( 6 )式は, 混合終 了時には付着粉の水分は $W_{\mathrm{Imc}}$ まで低下寸る結果に基づいて いる。(6)式より粉付着率 $R_{2}$ は混合直後の付着粉水分 $\left(w_{1}\right)$ に依存する。

$$
\begin{aligned}
& D_{2} / D_{c}=\left(\left(M_{c}+M_{f} \cdot R_{2} /(1-\varepsilon)\right) / M_{c}\right)^{1 / 3} \\
& M_{f}\left(R_{2}-R_{1}\right)=M_{f} \cdot R_{1} \cdot\left(\left(w_{1}-W_{\mathrm{lmc}}\right) /\left(W_{\mathrm{lim}}-W_{b}\right)\right)
\end{aligned}
$$

ここで, $R_{2}$ は混合終了時の付着粉率(一), $W_{\mathrm{b}}$ は混合直後 の未付着粉平均水分 $(\mathrm{mass} \%)$ で, (7)式で算出される。

$$
W_{b}=\int_{W_{\mathrm{itm}}}^{W_{\mathrm{tim}}} F_{1} \cdot w d w / \int_{W_{\mathrm{itm}}}^{W_{\mathrm{itm}}} F_{1} d w
$$


また, (6)式は粉全体の水分 $\left(W_{\text {ave }}(\operatorname{mass} \%)\right)$ が $W_{\text {lim }}$ 以下の 場合に成立する。 $W_{\text {ave }}$ が $W_{\text {lim }}$ を越えると粉の水分が $W_{\text {lim }}$ に 低下する前に粉がなくなる。よって，(8)式が成立する定 数 $p$ を用いて，(6)式は(9)式に修正される。

$$
\begin{gathered}
M_{f}\left(R_{2}-R_{1}\right)=p M_{f} \cdot R_{1} \cdot\left(\left(w_{1}-W_{\operatorname{lmc}}\right) /\left(W_{\lim }-W_{b}\right)\right) \cdots \cdots \cdots \cdots \cdot(8) \cdots \cdots \\
\int_{W_{\lim }}^{\infty} p \cdot M_{f} \cdot R_{1} \cdot\left(\left(w_{1}-W_{\lim }\right) /\left(W_{\lim }-W_{b}\right)\right) d w_{1}=\left(1-R_{1}\right) M_{f}
\end{gathered}
$$

高速筧找ミキサーによる混合では，粉の付着結合の前に 粉の水分が均一化するので, 混合終了時の付着粉率 $\left(R_{2}\right)$ は (10)式で記載され，擬似粒子径は一定值になる。

$$
\begin{aligned}
R_{2}=1 & \left(W_{\text {ave }} \geqq W_{\text {lim }}\right) \\
=0 & \left(W_{\text {ave }} \leqq W_{\text {lim }}\right)
\end{aligned}
$$

以上のモデルの精度を確認するために，モデル原料造粒 実験における実測值と計算值を比較した。実験における水 分添加方法より，ドラムミキサーのみの混合の場合，水分 添加段階での粉の質量分布関数は(11)式および(12)式のよ うな一様分布を仮定した。

$$
\begin{aligned}
& F_{1}=M_{f} /\left(W_{\max }-W_{\text {int }}\right) \quad\left(W_{\text {int }} \leqq W \leqq W_{\text {max }}\right) \\
& =0 \quad\left(W \leqq W_{\text {int }}, W_{\max } \leqq W\right) \\
& W_{\text {max }}=2 W_{\text {ave }}-W_{\text {int }}
\end{aligned}
$$

モデル計算結果と実験結果を Fig.10に示すが，対応は良 好であった。この結果から，粗粒に高水分粉，次いで低水 分粉が付着し，かつ崩壊は起こらないドラムミキサーの混 合特性，および付着結合と崩壊の双方が同時に起こる高速 撌拌ミキサーの混合特性の考え方は妥当であると考えられ る。

\section{$4 \cdot 4$ 擬似粒子形成における適正水分分布と造粒法}

擬似粒子内に存在し付着結合として機能する水分や擬似 粒子表層に存在する水分は，吸水未飽和鉱石中へ移動する。 この水分移動は擬似粒子を崩壊させる可能性がある。しか し省エネルギーの観点から鉱石中の水分は付着結合に関与 しないので，その水分は低い方が望ましい。むろん，付着 粉として機能する粉鉱石には，付着力を発現すべくその表 層部に水分を保持する必要があるので粉内への吸水は避け られない。従って，粗粒鉱石について，混合前後を通じて 鉱石への吸水を抑制する必要がある。

一方，粉鉱石については，初期水分と添加水分との和が 一定であればその初期水分を付着限界水分 $\left(W_{\mathrm{lim}}\right)$ 以上に高 めることによって，水添加時に水分の質量分布が狭くでき， 擬似粒度が均一化できる。これは，擬似粒径が $10 \mathrm{~mm}$ 以上 になると粒子内への燃焼酸素供給や伝熱の面で悪影響が現 れるので，造粒においては未付着粉を減少させると同時に $10 \mathrm{~mm}$ 以上の擬似粒子も減少させることが重要とされてい

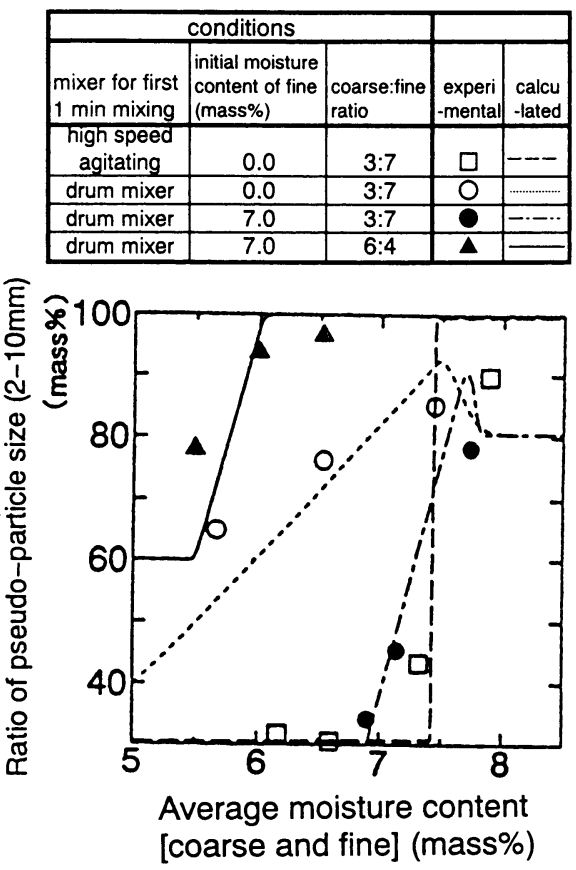

Fig. 10. Comparison between calculating and experimental results for pseudo-particles size distribution.

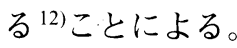

以上より, 粗粒鉱石は乾燥させ, 粉鉱石は水分を $W_{\lim }$ で 強隐拌作用により均一に調湿する。その後，粗粒鉱石と粉 鉱石を転動処理し, 粗粒鉱石内部への吸水前に焼結するこ とが望ましい。

\section{5. 結言}

焼結鉱製造における原料水分に関する実験と考察を行 い，以下の知見が得られた。

（1）原料中の水分は，付着粉粒子間より鉱石内気孔の 方が安定に存在する。乾燥粗粒鉱石が水で飽和するのに5 時間以上要する。よって，水分が未飽和のままで造粒した 場合には，造粒後に擬似粒子が崩壊することが考えられ る。

（2）高水分付着粉を外殻とする擬似粒子へ低水分粉を 付着させていくと，付着粉の水分は一定值に収束する。

（３）ドラムミキサーによる混合によって，まず高水分 の粉鉱石が粗粒鉱石に付着し，しかる後に低水分の粉鉱石 が既付着粉と合体する。混合前における原料粉鉱石の水分 分布と粉鉱石比率によって，造粒後の擬似粒度分布が決定 される。粉鉱石の水分が不均一な程，また粉鉱石比率が高 い程，擬似粒度分布の幅が広がる。

（4）高速摫拌ミキサーによる混合では，粉鉱石が付着 成長せずに水分が均一化する。これは，粉鉱石の付着と崩 壊の双方が生じていることによる。

（５）ドラムミキサーによる混合に先立ち高速擋拌ミキ サーで混合すると, 最終的には擬似粒度分布の幅を狭める 
ことができる。

（6）今回の検討では，粉のみで構成される擬似粒子の 存在を無視したが，粗粒と粉の水分条件によってはこの型 の擬似粒子も生成されることが考えられる。今後の研究課 題である。

\section{文献}

$1)$ E.A.Voice and R.Wind: Iron Coal Trades Rev., 11 (1957), 841.

2 ) Y.Hida, K.Itou, J.Okazaki, M.Sasaki and Y.Umezu: Tetsu-to-Hagané, $\mathbf{6 8}(1982), 2166$.

3 ) S.Satou, M.Yoshinaga, M.Ichidate and T.Kawaguchi: Tetsu-toHagané, 68 (1982), 2174.
4) S.Suzuki, K.Satou and M.Fujimoto: Tetsu-to-Hagané, 73 (1987), 1932.

5) M.Wajima, Y.Hosotani, M.Shibata, H.Souma and K.Tashiro: Tetsu-toHagané, 68 (1982), 1719.

6) A.G.Water, J.D.Lister and S.K.Nicol: ISIJ Int., 29 (1989), 274.

7) J.Kano, N.Chujo and F.Saito: Adv. Powder Technol., 8 (1997), 39.

8) T.Kawaguchi, K.Kuriyama, S.Satou and K.Takada: Tetsu-to-Hagané, 76 (1990), 1642.

9) Y.Hida: Tetsu-to-Hagané, 81 (1995), 263.

10) R.Nakajima, S.Kurosawa, M.Fukuyo, Y.Matsunaga and T.Wada: CAMP-ISIJ, 2 (1989), 937.

11) K.Satou, S.Suzuki, M.Fujimoto and Y.Shimomura: Tetsu-to-Hagané, 71 (1985), S21.

12) M.Matsumura, T.Kawaguchi, M.Yariyama, K.Tajiri and Y.Hadano: Proc. 6th. Int. Symp. on Agglomeration, Soc. Powder Technol., Jpn., ISIJ, and Soc. Chem. Eng., Jpn., Kyoto, (1993), 180. 